\title{
Improving PPKN Learning Outcomes using Audio Visual Media
}

\author{
Dwi Ganis Noviyanti \\ SDN Karangayu 03 Semarang \\ dwiganis_004@yahoo.com
}

\section{Article History}

accepted 14/11/2020

approved $21 / 11 / 2020$

published 26/11/2020

\begin{abstract}
The use of appropriate media in the teaching and learning process will create a pleasant learning atmosphere. In the teaching and learning process, teachers are expected to provide teaching that is easily understood by students. One of the learning media that can be used to improve learning outcomes of PPKN subjects in the precepts of Pancasila is audio visual media. This research is a classroom action research conducted in three cycles consisting of the stages of planning, action, observation, and reflection. Data obtained from teacher observations in managing learning, observations of student activities in the learning process, and student learning test results. The data analysis technique used is quantitative techniques. The results showed that the students' learning outcomes using audio-visual media in the first cycle had an average value of 76 . In the second cycle the average value was 84 and in the third cycle the average value was 86 . Based on the results of data analysis, it can be concluded that the use of audio media visuals are very suitable for use in learning and can improve learning outcomes.
\end{abstract}

Keywords: learning outcome, audio visual media

\begin{abstract}
Abstrak
Penggunaan media yang tepat dalam proses belajar mengajar akan menjadikan suasana belajar yang menyenangkan. Dalam proses belajar mengajar, guru diharapkan dapat memberikan pengajaran yang mudah dipahami oleh siswa. Salah satu media pembelajaran yang dapat digunakan untuk meningkatkan hasil belajar mata pelajaran PPKN materi sila pada Pancasila adalah media audio visual. penelitian ini merupakan penelitian tindakan kelas yang dilakukan dalam tiga siklus terdiri dari tahapan perencanaan, tindakan, observasi, dan refleksi. Data diperoleh dari pengamatan guru dalam mengelola pembelajaran, pengamatan aktivitas siswa dalam proses belajar, dan hasil tes belajar siswa. Teknik analisis data yang digunakan yaitu teknik kuantitatif. Hasil penelitian menunjukkan bahwa hasil belajar siswa dengan menggunakan media audio visual pada siklus I nilai rata-rata 76. Pada siklus II memperoleh nilai rata-rata 84 dan pada siklus III nilai rata-rata 86 . Berdasarkan hasil analisis data dapat disimpulkan bahwa penggunaan media audio visual sangat cocok di gunakan pada pembelajaran dan dapat meningkatkan hasil belajar
\end{abstract}

Kata kunci: hasil belajar, media audio visual

Social, Humanities, and Education Studies (SHEs): Conference Series https://jurnal.uns.ac.id/shes

p-ISSN 2620-9284

e-ISSN 2620-9292 


\section{PENDAHULUAN}

UU Nomor 20 Tahun 2013 pasal 3 menyatakan Pendidikan nasional berfungsi mengembangkan kemampuan dan membentuk watak serta peradaban bangsa yang bermartabat dalam rangka mencerdaskan kehidupan bangsa, bertujuan untuk mengembangkan potensi siswa agar menjadi manusia yang beriman dan bertakwa kepada Tuhan Yang Maha Esa, berakhlak mulia, sehat, berilmu, cakap, kreatif, mandiri, dan menjadi warga negara yang demokratis serta bertanggung jawab.

Menurut Sukewi (1994:23) proses pendidikan diselenggarakan secara formal di sekolah, dimaksudkan untuk mengarahkan perubahan pada diri seseorang secara terencana, baik dalam aspek pengetahuan, keterampilan maupun sikap. Dalam proses pembelajaran terdapat komponen-komponen yang saling terkait, yang meliputi tujuan pengajaran, guru dan peserta didik, bahan pelajaran, metode/strategi belajar mengajar, alat/media, sumber pelajaran dan evaluasi.

Guru mempunyai peran yang sangat penting dalam meningkatkan mutu pembelajaran karena terlibat langsung dalam upaya membina dan mengembangkan kemampuan siswa. Selain itu media yang digunakan juga sangat berpengaruh dalam menyampaikan materi karena apabila guru dapat menyajikan materi pembelajaran dengan menggunakan media yang menarik maka dapat meningkatkan minat belajar siswa dan memudahkan siswa dalam memahami pelajaran sehingga berpengaruh terhadap hasil belajarnya.

Pada saat pembelajaran daring tematik terpadu Tema 3 Kegiatanku Subtema 1 Kegiatanku di Pagi Hari muatan pembelajaran PPKN, media pembelajaran yang digunakan masih konvensional atau berupa teks bacaan. Guru hanya memberikan tugas anak membaca buku paket dan pemberian soal Guru tidak melibatkan siswa secara langsung dalam pembelajaran, siswa hanya objek pendidikan. Guru belum menggunakan media pembelajaran yang bervariasi pada pembelajaran yang sesuai dengan hakekat dan karakteristik materi pembelajaran

Dengan hanya membaca teks bacaan menjadikan minat untuk belajar siswa kurang. Dampak minat belajar yang berkurang adalah konsep konsep dari materi pembelajaran tidak bisa diterima dengan baik oleh siswa, akibatnya hasil belajar siswa menjadi kurang maksimal. Oleh karena itu untuk menyiasati dalam pembelajaran daring, perlu menggunakan media pembelajaran yang bisa menumbuhkan minat siswa untuk mengikuti pembelajaran yang diadakan, baik dikelas online maupun mandiri sehingga berdampak pada hasil belajar siswa yang lebih maksimal.

Salah satu media pembelajaran yang akan menunjang pembelajaran yaitu media audio visual. Asyhar (2011:45) menjelaskan media audio visual merupakan media pembelajaran yang dapat melibatkan penglihatan dan pendengaran pada suatu proses kegiatan. Pesan dan informasi yang dapat disalurkan melalui media ini dapat berupa pesan verbal dan nonverbal yang mengandalkan baik penglihatan maupun pendengaran. Beberapa contoh media audio visual adalah film, video, program TV dan lain-lain karena media pembelajaran ini memberikan gambaran secara konkrit pembelajaran yang akan disampaikan.

Penggunaan media audio visual sangat berkaitan dengan pembelajaran terutama bagi siswa yang masih kurang dalam memahami pelajaran. Dalam hal ini media audio visual dapat digunakan sebagai alat untuk mendemonstrasikan sebuah konsep, memperjelas pesan pembelajaran dan memberikan penjelasan yang lebih kongkrit, selain itu media audio visual ini juga dapat meningkatkan pemahaman siswa karena siswa tidak hanya mendengarkan tetapi juga dapat melihat materi yang ditayangkan dengan lebih bervariasi.

Arsyad (2011: 49-50) mengungkapkan beberapa kelebihan media audio visual dalam pembelajaran adalah film dan vidio dapat melengkapi pengalaman dasar siswa, dapat menggambarkan suatu proses secara tepat yang dapat disaksikan secara berulang-ulang jika perlu, mendorong dan meningkatkan motivasi, menanamkan sikap 
sikap dan segi afektif lainnya., film dan video yang mengandung nilai-nilai positif dapat mengundang pemikiran dan pembahasan dalam kelompok siswa, Film dan video dapat menyajikan peristiwa yang berbahaya jika dilihat secara langsung, film dan video dapat ditunjukkan kepada kelompok besar atau kelompok kecil, kelompok yang heterogeny maupun homogen maupun perorangan, film yang dalam kecepatan normal memakan waktu satu minggu dapat ditampilkan dalam satu atau dua menit

Secara umum tujuan dari penelitian ini adalah untuk mengetahui hasil belajar siswa kelas I SDN Karangayu 03 Semarang. Sedangkan secara khusus penelitian ini bertujuan meningkatkan aktivitas siswa dan meningkatkan hasil belajar siswa setelah guru menggunakan media audio visual dalam pembelajaran tematik terpadu muatan pelajaran PPKN materi sila pada Pancasila di kelas I SDN Karangayu 03 Semarang Tahun Pelajaran 2020/2021.

\section{METODE}

Penelitian ini adalah penelitian tindakan kelas (Classroom Action Research) dengan menggunakan media audio visual. Menurut Hopkins (1993), penelitian tindakan kelas diawali dengan perencanaan tindakan (Planing), penerapan tindakan (action), mengobservasi dan mengevaluasi proses dan hasil tindakan (Observation dan evaluation). Sedangkan prosedur kerja dalam penelitian tindakan kelas terdiri atas empat komponen, yaitu perencanaan (planning), pelaksanaan (action), pengamatan (observing), dan refleksi (reflecting), dan seterusnya sampai perbaikan atau peningkatan yang diharapkan tercapai (kriteria keberhasilan).

Analisis penelitian ini adalah analisis deskriptif kuantitatif di mana dalam penyajian hasil berupa data angka dan disertai dengan cara pengolahan hasil penelitian dan pembuatan analisis dalam penerapan media audio visual. Penelitian ini dilaksanakan pada 28 siswa kelas I SDN Karangayu 03 Semarang Tahun Pelajaran 2020/2021 selama tiga siklus secara daring menggunakan aplikasi Google meet pada siklus I dan II dan aplikasi Zoom pada siklus III. Pelaksanaan siklus I pada tanggal 2 November 2020. Siklus II pada tanggal 9 November 2020. Siklus III pada tanggal 20 November 2020. Teknik pengumpulan data yang dilakukan dengan observasi dn tes, baik pretest maupun postest. Observasi meliputi pengamatan keterlaksanaan pembelajaran daring dengan menggunakan media audio visual, keaktivan siswa selama pembelajaran dan ketrampilan. Untuk hasil belajar menggunakan tes melalui Google form.

HASIL DAN PEMBAHASAN

Hasil penelitian menunjukkan peningkatan hasil belajar tematik terpadu muatan pelajaran PPKN materi sila pada Pancasila, terlihat pada tabel dan diagram berikut

Tabel 1. Hasil Belajar Siswa

\begin{tabular}{llcccc}
\hline No. & Range Nilai & \multicolumn{4}{c}{ Jumlah Siswa } \\
& & Pretest & Siklus I & Siklus II & Siklus III \\
\hline $\mathbf{1}$ & $81-100$ & 2 & 7 & 13 & 24 \\
$\mathbf{2}$ & $61-80$ & 13 & 12 & 15 & 4 \\
$\mathbf{3}$ & $41-60$ & 10 & 9 & 0 & 0 \\
$\mathbf{4}$ & $21-40$ & 3 & 0 & 0 & 0 \\
$\mathbf{5}$ & $0-20$ & 0 & 0 & 0 & 0 \\
\hline
\end{tabular}




\section{Gambar 1. Perbandingan Nilai Rata-rata Kelas Hasil Belajar Siswa}

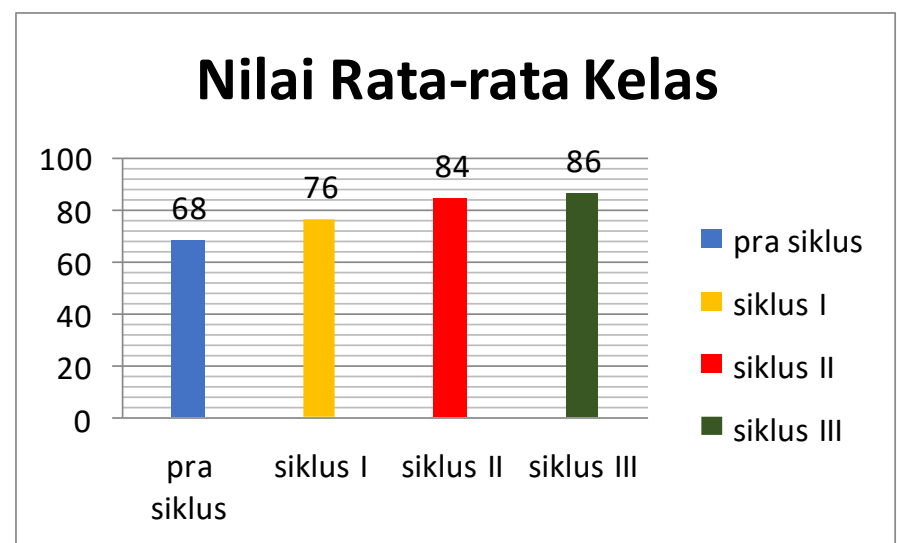

Gambar 2. Perbandingan Prosentase Kriteria Ketuntasan Minimal Tiap Siklus

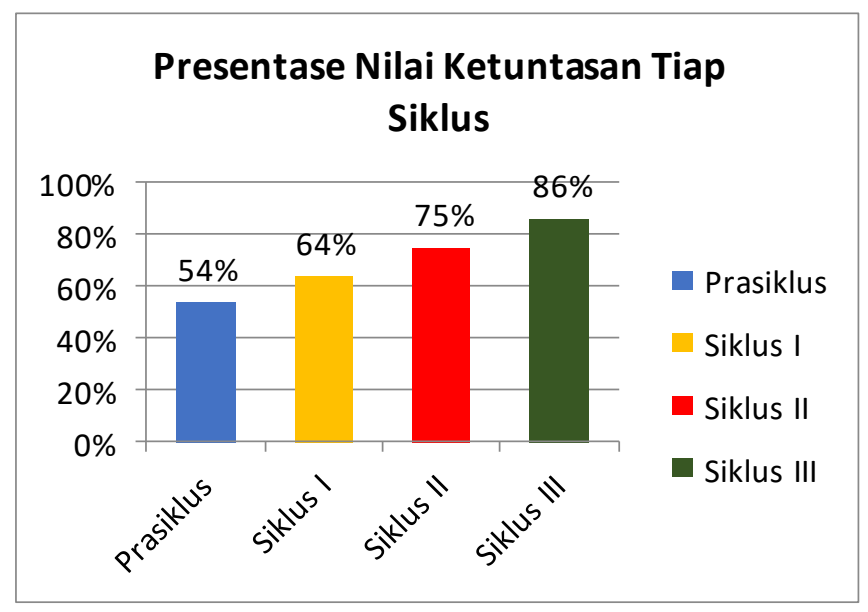

Untuk mengetahui kondisi awal hasil belajar siswa sebelum dilakukan penelitian maka pengambilan data hasil belajar siswa dengan pre test terlebih dahulu. Kegiatan ini diikuti seluruh siswa kelas I SDN Karangayu 03 Semarang Tahun Pelajaran 20202/2021 yang berjumlah 28 siswa. Data yang diambil berupa hasil penilaian soal evaluasi pada pembelajaran tematik terpadu muatan pelajaran PPKN dengan materi sila pada Pancasila. Teknik tes dilakukan untuk mengumpulkan hasil belajar siswa. Soal tes evaluasi berbentuk pilihan ganda sebanyak 10 soal yang dibagikan melalui Google form.

Berdasarkan data diagram perbandingan hasil belajar pada pra siklus, nilai rata - rata kelas hanya 68 dengan ketuntasan klasikal 54\% ini menunjukkan bahwa daya serap masih jauh dibawah standar. Hal ini disebabkan siswa kurang memahami penjelasan guru tanpa media pembelajaran yang mendukung. Pembelajaran berpusat pada guru, siswa kurang diajak berpartisipasi dalam KBM. Saat pembelajaran daring metode yang digunakan guru lebih banyak ceramah daripada memvariasikan media pembelajaran dan metode pembelajaran yang digunakan. Siswa diberi tugas untuk mmebaca teks kemudia mengerjakan soal evaluasi. Siswa tidak antusias saat pembelajaran, banyak yang tidak memperhatikan saat guru menjelaskan. Siswa terlihat tidak memahami materi pembelajaran sehingga ketika diadakan tes akhir 
banyak yang mendapat nilai di bawah KKM yaitu sebanyak 13 siswa. Sebanyak 15 siswa sudah mencapai nilai di atas KKM. Kriteria Ketuntasan Minimal pada matan pembelajaran PPKN adalah 75.

Mengingat pentingnya materi sila pada Pancasila dalam muatan pelajaran PPKN, maka peneliti akan melakukan perbaikan pembelajaran siklus I dengan menggunakan media audio visual. Media audio visual yang digunakan guru berupa siswa mendengarakn cerita dari video yang diputar melalui power point. Pada siklus ini peneliti menitikberatkan pada peningkatan hasil belajar serta peningkatan aktivitas belajar siswa dengan menggunakan media audio visual. Ternyata hasil yang diperoleh nilai rata - rata kelas pada siklus II menjadi 75 dengan prosentase ketuntasan belajar dari $54 \%$ menjadi $64 \%$. Ini berarti ada kenaikan nilai rata - rata kelas sebesar 8 poin dan kenaikan ketuntasan belajar $10 \%$. Dengan perolehan nilai tersebut menunjukkan perbaikan pembelajaran siklus I cukup efektif dan berhasil dalam meningkatkan aktivitas belajar siswa, namun masih ada 10 siswa mendapatkan nilai dibawah KKM. Oleh karena itu berdasarkan lembar observasi siklus I, maka perlu perbaikan pembelajaran siklus II.

Pada siklus II ini peneliti menitik beratkan pada peningkatan hasil belajar dan peningkatan aktivitas belajar peserta didik dalam proses pembelajaran menggunakan media audio visual. Media Audio Visual yang digunakan guru berupa video lagu serta video materi sila pada Pancasila yang bersumber dari yotube. Dari data hasil belajar pada siklus II ada peningkatan respon siswa terhadap tugas dari guru. Hasil penelitian menunjukkan adanya peningkatan aktivitas belajar dan prestasi belajar siswa, dari 28 siswa yang memperoleh nilai 75 ke atas sebanyak 21 siswa sedangkan 7 siswa belum mencapai ketuntasan klasikal, sehingga ketuntasan klasikalnya $75 \%$. Hal ini menunjukkan adanya peningkatan prestasi belajar siswa pada siklus II.

Dari diagram tersebut dapat dikemukakan peningkatan aktivitas guru dibandingkan pada saat siklus sebelumnya, antara lain secara garis besar guru sudah menerapkan pembelajaran dengan menggunakan media audio visual dengan baik dan guru sudah banyak melibatkan siswa dalam proses pembelajaran dan perannya sudah tidak terlalu dominan. Guru menggunakan media audio visual tersebut secara maksimal dan dapat meningkatkan motivasi serta minat siswa untuk belajar. Namun dari pelaksanaan perbaikan pembelajaran siklus II ini ada kekurangan yang dilakukan guru yaitu, guru belum dapat menuntaskan belajar seluruh siswa, masih ada 7 siswa yang tidak mencapai ketuntasan dalam belajar. Hal ini terjadi karena siswa-siswa tersebut memang tergolong siswa yang memiliki tingkat kecerdasan yang rendah sehingga mereka kesulitan untuk mengikuti proses pembelajaran. Dari data pada siklus II ini, maka dilakukan perbaikan melalui pembelajaran daring menggunakan media audio visual guna meningkatan ketuntasan belajar kelas pada siklus III.

Pada siklus III prosentase nilai ketuntasan mencapai 86\% dengan 24 siswa sudah mencapai nilai di atas KKM dan 4 siswa yang belum mencapai KKM. Dari hasil penelitian dapat dilihat pada diagram 1 dan diagram 2 menunjukkan bahwa data hasil belajar dari pratindakan hingga siklus III mengalami peningkatan. Dengan nilai rata rata kelas mencapai 86 pada siklus III. Dari data hasil belajar di siklus III ini terdapat kenaikan pada nilai rata-rata kelas sebanyak 2 poin.

Berdasarkan tabel dan diagram hasil belajar siswa dengan menggunakan media audio visual dapat dilihat bahwa siswa sangat tertarik selama kegiatan pembelajaran. (luqman et al., 2017) menyatakan bahwa pembelajaran yang menyenangkan, menarik minat dan tidak membosankan siswa merupakan salah satu awal pembelajaran menjadi bermakna yang pada kahirnya dapat meningkatkan hasil belajar siswa. 


\section{SIMPULAN}

Hasil penelitian menunjukkan bahwa hasil belajar tematik terpadu muatan pelajaran PPKN materi sila pada Pancasila siswa kelas I SDN Karangayu 03 Semarang Tahun pelajaran 2020/2021 meningkat setelah menggunakan media audio visual. Siswa termotivasi dalam pembelajaran. Media audio visual dapat menarik minat dan keaktifan siswa dalam kegiatan pembelajaran daring tema 3 subtema 1 muatan pembelajaran PPKN. Hal ini sangat berpengaruh terhadap peningkatan hasil belajarn siswa yang dengan ketuntasan hasil belajar pada siklus I $64 \%$ menjadi $86 \%$ pada siklus III.

Berdasarkan hasil penelitian tindakan kelas yang dilakukan oleh guru dapat melibatkan siswa dalam pemanfaatann kemajuan teknologi dengan penggunaan media audio visual sehingga siswa lebih menguasai materi pembelajaran secara kontekstual dengan hasil belajar yang juga meningkat.

\section{DAFTAR PUSTAKA}

Arikunto, Suharsimi. 2010. Penelitian Tindakan Kelas. Yogyakarta: Aditya Media. Arsyad, Azhar. 2011. Media Pembelajaran. Jakarta: PT Raja Grafindo Persada.

Asyhar, Rayanda. 2011. Kreatif Mengembangkan Media Pembelajaran. Jakarta: Gaung Persada (GP) Press Jakarta.

Kemendikbud. 2013. Kerangka Dasar Kurikulum 2013. Jakarta: Kementerian

Pendidikan dan Kebudayaan tahun 2013 Badan Standar Nasional Pendidikan

Sukewi Sugito. 1994. Perencanaan Pengajaran. IKIP. Semarang Press, Semarang 